\title{
SPECIAL TOOLS FOR THE DEVELOPMENT OF REGIONS OF RUSSIA AS A RESOURCE OF INTERREGIONAL INTEGRATION ${ }^{1}$
}

\author{
Nikolay W. Gontar \\ Southern Federal University, Rostov-on-Don, Russian Federation
}

\begin{abstract}
The diversity of regional situations in Russia requires a differentiated approach to building regional policies for different types of regions. Under this approach, a number of instruments have been developed to promote regional development, however they are based on the separation of regions and the strengthening of their vertical linkages. At the same time, the resource of synergistic development through interregional interaction remains virtually unused. In this regard, the purpose of the article was to inventory the existing special regimes of regional development (special economic zones, clusters, regions of a special type, territories of advanced development and others), identify legislative opportunities for implementing interregional cooperation within their framework, and analyze actual results of such instruments in Russia. Based on the analysis of the legislative framework and the practice of using the special instruments under consideration, a range of measures has been formulated to accelerate their effectiveness in the methodological and institutional sphere. A range of mechanisms that will allow the inclusion of the criterion of interregional cooperation in the structure of relevant instruments is proposed. At the same time, the fact of differentiation of possible additional (involving interregional ties) mechanisms depending on the type of region and the purpose of the implemented special development formats is taken into account.

Key words: interregional integration, special economic zones, clusters, regional development, regional policy.

Citation. Gontar N.W. Special Tools for the Development of Regions of Russia as a Resource of Interregional Integration. Journal of Volgograd State University. Economics, 2020, vol. 22, no. 3, pp. 42-52. (in Russian). DOI: https://doi.org/10.15688/ek.jvolsu.2020.3.4
\end{abstract}

УДК 332.122 .5

Дата поступления статьи: 03.08.2020

ББК 65.9

Дата принятия статьи: 25.09.2020

\section{СПЕЦИАЛЬНЫЕ ИНСТРУМЕНТЫ РАЗВИТИЯ РЕГИОНОВ РОССИИ КАК РЕСУРС МЕЖРЕГИОНАЛЬНОЙ ИНТЕГРАЦИИ ${ }^{1}$}

\author{
Николай Владимирович Гонтарь \\ Южный федеральный университет, г. Ростов-на-Дону, Российская Федерация
}

\begin{abstract}
Аннотация. Многообразие траекторий развития регионов России требует дифференцированного подхода к выстраиванию региональной политики в отношении регионов разного типа. В рамках такого подхода создан ряд инструментов содействия региональному развитию, которые, однако, основаны на обособлении регионов и упрочении их вертикальных связей. В то же время фактически незадействованным остается ресурс синергичного развития посредством межрегионального взаимодействия. В этой связи целью статьи была инвентаризация существующих специальных инструментов регионального развития (особые экономические зоны, кластеры, регионы особого типа, территории опережающего развития и иные), выявление законодательных возможностей реализации в их рамках межрегионального взаимодействия, анализ фактических результатов деятельности таких инструментов в России. На основе анализа законодательной базы и практики использования рассматриваемых специальных инструментов сформулирован круг мер акселерации их действенности в методологической и институциональной сферах. Предложен спектр механизмов, которые позволят включить элемент межрегионального сотрудничества в структуру соответствующих инструментов. При этом учтен факт дифференциации возможных дополнительных (вовлекающих в развитие межрегиональные связи) механизмов в зависимости от типа региона и целевого назначения реализуемых особых форматов развития.
\end{abstract}


Ключевые слова: межрегиональная интеграция, особые экономические зоны, кластеры, региональное развитие, региональная политика.

Цитирование. Гонтарь Н. В. Специальные инструменты развития регионов России как ресурс межрегиональной интеграции // Вестник Волгоградского государственного университета. Экономика. - 2020. T. 22, № 3. - C. 42-52. - DOI: https://doi.org/10.15688/ek.jvolsu.2020.3.4

\section{Введение}

Проблематика механизмов регионального развития в условиях значимых вызовов глобального и общероссийского масштаба представляется актуальным направлением поиска стратегий долгосрочного роста. Сегодня требующими нестандартных управленческих решений вызовами для регионов России выступают: долгосрочное замедление экономики, ее структурный кризис, сокращение экономической активности ввиду противодействия пандемии коронавирусной инфекции COVID-19, кризис на сырьевых рынках.

Механизмы межрегионального взаимодействия представляют собой ресурс развития, позволяющий одновременно ослабить влияние внешних шоков и реализовать внутренние ресурсы развития. В этой связи целью статьи является анализ механизмов межрегионального взаимодействия, специальных инструментов развития регионов в России (особые экономические зоны, кластеры и др.), а также межрегиональной составляющей таких инструментов и перспектив ее институциализации.

\section{Методика исследования}

Исследования межрегиональной интеграции сегодня сосредоточены на связях между субъектами РФ [Лукин, 2012; Гибадуллин и др., 2013], анализе такой интеграции как инструмента преодоления дезинтеграционных тенденций в экономическом пространстве [Топилин, 2015; Борщик, 2016], формировании продовольственных связей [Алтухов, 2017], исследовании интеграции как фактора региональной конкурентоспособности [Ахунов, 2016]. Особое значение межрегиональное взаимодействие имеет для развития периферийных регионов [Бакуменко, 2017]. При этом реализация соответствующих стратегий возможна в условиях регулирования межрегиональных процессов [Колодина, 2003], в том числе на основе стандартизированных административных процедур [Методические рекомендации ... , 2010] и ресурсов межмуниципальных связей [Ручкин, 2014].

Институциональные «рамки» межрегионального сотрудничества в РФ к началу 2000-х гг. были заданы в Федеральным законом от 17.12.1999 № 211-Ф3 «Об общих принципах организации и деятельности ассоциаций экономического взаимодействия субъектов РФ». Сегодня приоритеты межрегионального сотрудничества отражены также в Стратегии пространственного развития Российской Федерации на период до 2025 г. (согласно Распоряжению Правительства РФ от 13.02.2019 № 207-p), а именно: сохранение высокого уровня межрегионального социально-экономического неравенства; невысокая межрегиональная и внутрирегиональная миграционная подвижность населения; нереализованный потенциал межрегионального и межмуниципального взаимодействия. Как следствие, к задачам Стратегии отнесены: сокращение уровня межрегиональной дифференциации, снижение внутрирегиональных социально-экономических различий за счет усиления межрегионального сотрудничества и координации социально-экономического развития субъектов и содействия развитию межрегионального и межмуниципального сотрудничества. Современная практика межрегиональной интеграции включает:

- взаимодействие сопредельных субъектов РФ и муниципалитетов на основе соглашений. Такие механизмы предусмотрены в законодательстве ограниченного числа субъектов, им присущи концентрация на представительских и культурно-просветительских контактах и мероприятиях, отсутствие экономического «измерения»;

- взаимодействие в рамках федеральных объединений административно-территориальных субъектов (Союз российских городов, Союз малых городов России, Ассоциации экономического взаимодействия и проч.); 
- формирование реальных межрегиональных взаимодействий в форме связей рыночных агентов, которые объединяют субподрядчиков, поставщиков и сбытовые единицы в десятках регионов. Однако межрегиональные стратегии компаний и их пространственные ориентиры обусловлены прежде всего географией ресурсов (что фрагментирует их деятельность и спектр охватываемых регионов) и рыночным потенциалом территорий (сокращение которого может ослабить активность компаний, вплоть до сворачивания деятельности).

Как следствие, современное состояние межрегионального взаимодействия характеризуется ограниченной действенностью. В этой связи в статье посредством институционального исследования и компонентного анализа определяются возможности и потенциал расширения межрегионального взаимодействия в рамках специальных инструментов развития.

\section{Основные результаты}

Специальные инструменты развития: современное состояние в России. Сегодня имеется широкая практика формирования преференциальных инструментов хозяйствования, предоставляющих возможность сократить транзакционные издержки бизнеса на выделенных ограниченных территориях.

Однако часть соответствующих механизмов в РФ замыкает меры поддержки регионов рамками самих субъектов, что формально обосновано исходя из целей содействия развитию конкретного субъекта Федерации. Таковы, например: особая экономическая зона (далее - ОЭЗ), действующая до 2045 г. в Калининградской области (Федеральный закон от 10.01.2006 № 16-Ф3 «Об Особой экономической зоне в Калининградской области и о внесении изменений в некоторые законодательные акты Российской Федерации»); ОЭЗ в границах г. Магадана, где уже 20 лет действует особый правовой режим хозяйственной деятельности и применяется таможенная процедура свободной таможенной зоны (Федеральный закон от 31.05.1999 № 104-Ф3); «Свободный порт Владивосток» (Федеральный закон от 13.07.2015 № 212-Ф3 «О свободном порте Владивосток»).
Сравнительно новый механизм - территории опережающего развития (далее ТОР) - применяется в 86 моногородах (из них 5 - в 3АТО), 19 ТОР созданы на Дальнем Востоке. ТОР в моногородах к середине 2019 г. насчитывали 370 резидентов, создали 14 тыс. рабочих мест и привлекли 24,2 млрд руб. инвестиций. Механизм ТОР также отличает построение по принципу региональных ячеек: территория опережающего социально-экономического развития определяется как часть территории субъекта РФ, включая закрытые административно-территориальные образования (ЗАТО), согласно Федеральному закону от 29.12.2014 № 473-Ф3 «О территориях опережающего социально-экономического развития в Российской Федерации. В соответствии со ст. 3, территории опережающего социальноэкономического развития (далее - ТОСЭР) создаются на территории муниципального образования или территориях нескольких муниципальных образований в границах одного субъекта РФ. Согласно ст. 12 , резиденты ТОСЭР не вправе иметь филиалы и представительства за ее пределами, а в соответствии со ст. 33, которая характеризует меры развития ДВФО, на Дальнем Востоке предполагалась разработка программ развития инвестиционной и предпринимательской деятельности для каждого субъекта РФ. «Точечность» ТОСЭР в ст. 34 также подтверждается тем, что механизм адресуется моногородам.

Связанным с уникальным положением и статусом и, как следствие, также регионально локализованным инструментом является статус «геостратегически значимых территорий», реализуемый посредством госпрограмм, например, в Калининградской области (госпрограмма «Социально-экономическое развитие Калининградской области» до 2025 г. включает 2 подпрограммы и Федеральную целевую программу (далее - ФЦП) развития Калининградской области на период до 2020 г.) и Республике Карелия (ФЦП «Развитие Республики Карелия на период до 2020 года»).

Кроме того, здесь можно упомянуть технопарки в развитых регионах, а также зоны территориального развития. Последние, согласно Федеральному закону от 03.12.2011 № 392-Ф3, - это часть территории субъекта РФ, где в целях ускорения социально-эконо- 
мического развития путем формирования благоприятных условий для привлечения инвестиций резидентам зоны предоставляются меры государственной поддержки.

Наконец, по тому же «ячеечному» принципу построена политика поддержки 10 регионов с низким уровнем социально-экономического развития (преимущественно национальных регионов Сибири, Северного Кавказа и европейской территории РФ, а также Псковской и Курганской областей) и поддержка моногородов.

Инструменты развития с элементами межрегионального взаимодействия. Потребность в интеграции (включая пространственную) ресурсов экономики, в том числе в рамках особых инструментов развития, в то же время осознана и сегодня реализована в рамках ряда механизмов. Так, согласно ЮНКТАД [Доклад ..., , 2019], в большинстве развивающихся и во многих развитых странах широко развиты особые экономические зоны. В этих районах государство содействует развитию промышленности с помощью налоговых и регулятивных льгот и инфраструктурной поддержки. Сегодня в 147 странах насчитывается почти 5400 зон и планируется создать еще свыше 500 ОЭЗ. В числе ОЭЗ выделяются свободные экономические зоны (СЭЗ), направленные на упрощение торговой логистики. В развивающихся странах используются интегрированные зоны с ориентацией на промышленное развитие, которые могут быть многоотраслевыми, специализированными или инновационными.

В России функционирует 30 ОЭЗ (13 промышленно-производственных, 6 технико-внедренческих, 10 туристско-рекреационных и 1 портовая). За 15 лет работы в ОЭЗ зарегистрировались более 760 резидентов, из которых более 140 - компании с участием иностранного капитала из 33 стран. Объем инвестиций в ОЭЗ превысил 420 млрд руб., создано более 38 тыс. рабочих мест, уплачено около 100 млрд руб. налогов, отчислений во внебюджетные фонды и более 50 млрд руб. таможенных платежей. С 1 июня 2020 г. в РФ также создаются новые ОЭЗ в Нижегородской области (промышленно-производственного типа, «Кулибин»), Республике Башкортос- тан (промышленно-производственного типа, «Алга») и Саратовской области (технико-внедренческого типа).

ОЭЗ в России обеспечивают инвесторам такие льготы, как 10-кратное сокращение налога на прибыль, обнуление налогов на имущество, землю и транспорт, а также НДС (в портовых зонах) на срок до 10 лет, радикальное сокращение цены приобретения земли. В 2019 г. 6 ОЭЗ РФ значились среди лучших ОЭЗ мира в рейтинге журнала «fDi Magazine» («The Financial Times»). ОЭЗ промышленно-производственного типа располагаются в промышленно и транспортно развитых регионах, с ресурсной базой и квалифицированным персоналом. Технико-внедренческие ОЭЗ располагаются в крупнейших научно-образовательных центрах, имеющих богатые научные традиции и исследовательские школы. Туристско-рекреационные ОЭЗ создаются для развития и оказания услуг в сфере туризма на одном или нескольких участках территории. Такие зоны опираются на ресурсы, имеющие межрегиональное распространение, в силу чего могут, например, на Северном Кавказе, где такие ОЭЗ созданы в 6 регионах, формировать межрегиональный вектор развития туристического комплекса. Портовые ОЭЗ создаются для организации судостроительной и судоремонтной деятельности, предоставления логистических услуг, базы для новых маршрутов. Их создание, однако, возможно на участках территории не более 50 кв. км, что исключает межрегиональный формат организации таких зон.

Говоря о достижении целей ОЭЗ, ЮНКТАД в то же время отмечает, что результаты работы многих зон неоднозначны: ОЭЗ не являются предварительным условием либо гарантией увеличения притока прямых иностранных инвестиций или участия стран в глобальных производственных цепочках. Там, где они способствуют экономическому росту, динамика чаще носит временный характер; многие зоны действуют как анклавы и оказывают ограниченное воздействие на экономику в целом.

Проблемные точки эффективности особых инструментов развития выявлены и в РФ [СП ..., 2020]. Отмечается, что они не ока- 
зывают прорывного влияния на экономику. Такие инструменты, за исключением ОЭЗ, pеализуются не более 4 лет. Следовательно, давать оценку их эффективности рано. Согласно оценкам [Отчет ...] на основании Постановления Правительства РФ от 07.07.2016 № 643 «О порядке оценки эффективности функционирования особых экономических зон», в 2018 г. функционирование ОЭЗ, без учета туристических, оценивалось как эффективное за 2018 г. и с начала функционирования ОЭЗ.

С 2014 г. ОЭЗ израсходовали 157 млрд руб. средств бюджетов разных уровней. Но $59 \%$ рабочих мест из 22 тыс. новых рабочих мест в 26 ОЭЗ к началу 2019 г. пришлось лишь на 4 ОЭЗ («Алабуга», «Технополис», «Липецк» и «Дубна»). Эти зоны и ОЭЗ «Санкт-Петербург» концентрируют и 82,9 \% объема выручки всех ОЭЗ с момента их создания. Все названные ОЭЗ - промышленнопроизводственные и высокотехнологичные площадки. Напротив, ОЭЗ туристско-рекреационного типа привлекли к 2019 г. лишь 0,6 \% общего объема инвестиций.

В то же время следует отметить, что хотя, согласно Федеральному закону от 22.06.2005 № 116-Ф3 «Об особых экономических зонах в Российской Федерации», резидент ОЭЗ не вправе иметь филиалы и представительства за пределами конкретной ОЭЗ, однако, в соответствии со ст. 4, ОЭЗ может располагаться на территории одного или нескольких муниципальных образований в пределах одного или нескольких субъектов РФ. Так, в 2007 г. по Соглашению между Ростовской областью и Краснодарским краем, на границе регионов была образована южная игорная зона (позже Ростовская область вышла из проекта).

Также необходимо обратить внимание на ресурс межрегионального сотрудничества в рамках механизма территориальных кластеров. Примеры стран Европы подтверждают возможность плодотворного сотрудничества субъектов кластеров и в сопредельных регионах («Медиконовая долина»), и в регионах, непосредственно не соседствующих друг с другом (кластер «Биодолина», действующий с 1996 г., расположен в регионах Франции, Швейцарии и Германии). Так, ареал «Биодолины» включает 4 университета, исследовательские центры, а объединение вокруг залива Эресунн (регионы Дании и Швеции) в рамках кластера "Долина Медикон» включает 26 больниц и 12 университетов [Смоленко, 2016].

Межрегиональный формат соразвития позволяет достичь плотности хозяйственных акторов, которая является одним из факторов формирования экономических импульсов и недостижима в рамках развития подобного рода инструментов в пределах одного региона. Также синергетический эффект достигается за счет отличий в сферах специализации. Например, в «Медиконовой долине» компании из Дании специализируются в области фармацевтики и медицинского оборудования, из Швеции - на разработках в области медицины и биотехнологий [Михайлов, 2013]. Межрегиональность способствует и росту числа вовлеченных квалифицированных кадров (так, «Биодолина» задействует 250 тыс. чел., или $10 \%$ от общего населения макрорегиона). В «Долине Медикон» функционирует 6 научно-технических парков, 6 бизнес-инкубаторов, 80 опытно-производственных организаций.

Фактором успеха межрегионального формата кластеризации является вовлечение в производственные процессы и связи транснациональных компаний (далее - ТНК): так, в «Биодолине» сосредоточены штаб-квартиры фармацевтических компаний «Novartis», «Roche», филиалы фармацевтических подразделений «Johnson and Johnson», «Pfizer» и др. [Смоленко, 2016]. Трансфер технологий в рамках ТНК выступает одним из ключевых преимуществ формирования межрегионального вектора сотрудничества, позволяя распространять передовые практики.

Также значительную роль в кластерном развитии северных стран сыграла государственная поддержка НИОКР: разработка нормативно-правовой базы и ее последующее совершенствование; формирование инновационной системы; организация венчурного финансирования; налаживание взаимодействия представителей предпринимательского и научно-образовательного секторов, инвестиционных компаний, общественно-государственных организаций; поддержка малого бизнеса [Михайлов, 2013]. 
В целом синергетический эффект развития межрегиональных кластеров и регионов их локализации связан с такими механизмами, как:

- рост объема производства и сбыта продукции на основе развития системы тесных взаимосвязей между фирмами, их поставщиками и клиентами, проведения маркетинговых исследований;

- более широкая дополнительная специализация производства в пределах каждой фирмы, общая закупка сырья для получения оптовых скидок;

- рост объемов экспорта, возможности более успешного выхода на международные рынки в результате устранения тарифных и нетарифных барьеров во взаимной торговле, упрощения внешнеторговых процедур, унификации требований к продукции и услугам в пределах кластера.

В России еще в 2012 г. Правительством РФ был утвержден Перечень инновационных территориальных кластеров (поручение Правительства РФ от 28.08.2012 № ДМ-П850600), куда вошли 27 кластеров. В $2016-$ 2017 гг. в рамках приоритетного проекта «Развитие инновационных кластеров - лидеров инвестиционной привлекательности мирового уровня» были отобраны 11 кластеров. Согласно С.Н. Котляровой, в России насчитывается также не менее 125 территориальных кластеров [Котлярова, 2012]. Сегодня в реестре Минпромторга РФ числится более 70 кластеров, в 2011 г. была создана Ассоциация кластеров и технопарков России, которая объединяет более 90 членов из 44 субъектов (более 2630 организаций).

В РФ на федеральном уровне реализуется программа поддержки пилотных инновационных территориальных кластеров Минэкономразвития России и программа поддержки промышленных кластеров Минпромторга России. В перечень Минэкономразвития России вошли пилотные инновационные территориальные кластеры таких технологических направлений, как ядерные и радиационные технологии; производство летательных и космических аппаратов, судостроение; фармацевтика, биотехнологии и медицинская промышленность; новые материалы; химия и нефтехимия; информационные технологии и электроника.
Промышленные кластеры - это, согласно Федеральному закону от 31.12.2014 № 488-Ф3 «О промышленной политике в Российской Федерации», совокупность предприятий, осуществляющих деятельность в сфере промышленности, связанных отношениями территориальной близости и функциональной зависимости и размещенных на территории одного или (что важно. - Н. Г.) нескольких регионов России.

С 2015 г. Минпромторг РФ поддерживает промышленные кластеры на базе Постановления Правительства от 31.07.2015 № 779. В настоящее время в составе кластеров, включенных в реестр министерства, значатся компании - технологические лидеры («ГАЗ», АО «Арнест», АО «Улан-Удэнский авиационный завод», АО «Монокристалл»), имеющие плотную производственную (и межрегиональную) кооперацию. Объем выпускаемой продукции предприятий превышает 1,3 трлн руб., или 1,4 \% от ВРП РФ.

Государственная финансовая поддержка участников промышленных кластеров (Постановление Правительства РФ от 28.01.2016 № 41) реализуется в форме субсидий из федерального бюджета на возмещение части затрат при реализации совместных проектов по производству импортозамещающей промышленной продукции. В 2016-2018 гг. одобрены 24 совместных проекта участников промышленных кластеров общей капиталоемкостью 21,8 млрд рублей. Межрегиональные промышленные кластеры позволяют повысить уровень взаимодействия промышленных предприятий нескольких регионов, создать кооперационные цепочки, расширить рынки сбыта продукции, учесть уже существующие межрегиональные кооперационные связи.

С 2019 г. действие Постановления РФ от 28.01.2016 № 41 распространяется исключительно на совместные проекты. Отобранные проекты уже реализуют свою продукцию внутри кластера и имеют гарантированный спрос со стороны других предприятий. Такой эффект обеспечил прирост налоговых отчислений в федеральный бюджет и появление свыше 1 тыс. высокопроизводительных рабочих мест. Межрегиональные кластеры, учитываемые сегодня в Реестре Минпромторга РФ, отражены в таблице 1. 


\section{Межрегиональные кластеры в Российской Федерации}

\begin{tabular}{|c|c|c|}
\hline Название кластера & Регионы & Специализация \\
\hline $\begin{array}{l}\text { Национальный аэрозольный } \\
\text { кластер }\end{array}$ & $\begin{array}{l}\text { Ставропольский край, } \\
\text { Карачаево-Черкесская } \\
\text { Республика, Тульская об- }\end{array}$ & $\begin{array}{l}\text { Производство бытовой химии, косметических } \\
\text { изделий в аэрозольной и полимерной упаковке, } \\
\text { производство сырья, полуфабрикатов и комплек- }\end{array}$ \\
\hline $\begin{array}{l}\text { Межрегиональный кластер } \\
\text { электронных приборов, ма- } \\
\text { териалов и компонентов }\end{array}$ & $\begin{array}{l}\text { Ставропольский край, } \\
\text { Белгородская область }\end{array}$ & Электроника \\
\hline $\begin{array}{l}\text { Промышленный кластер } \\
\text { «Композиты без границ» }\end{array}$ & $\begin{array}{l}\text { Республика Татарстан, } \\
\text { Саратовская и Москов- } \\
\text { ская области }\end{array}$ & $\begin{array}{l}\text { Композитные материалы, включая углеродное } \\
\text { волокно, стекловолокно, базальтовое волокно, } \\
\text { ткани }\end{array}$ \\
\hline $\begin{array}{l}\text { «Воронежский насосо- } \\
\text { строительный кластер» }\end{array}$ & $\begin{array}{l}\text { Воронежская и Липецкая } \\
\text { области }\end{array}$ & $\begin{array}{l}\text { Спецтехника оборонного назначения, нефтяные, } \\
\text { химические, шламовые насосы и техника граж- } \\
\text { данского назначения }\end{array}$ \\
\hline $\begin{array}{l}\text { Кластер в сфере легкой } \\
\text { промышленности }\end{array}$ & $\begin{array}{l}\text { Челябинская область, Рес- } \\
\text { публика Башкортостан }\end{array}$ & $\begin{array}{l}\text { Экипировка для армии и экстрима: обувь, гео- } \\
\text { текстиль, шлемы виртуальной реальности }\end{array}$ \\
\hline $\begin{array}{l}\text { Межрегиональный авиаци- } \\
\text { онный кластер }\end{array}$ & $\begin{array}{l}\text { Нижегородская, Ульянов- } \\
\text { ская и Иркутская области }\end{array}$ & $\begin{array}{l}\text { Разработка и производство инновационного } \\
\text { среднемагистрального авиалайнера МС-21 }\end{array}$ \\
\hline Нефтехимический кластер & $\begin{array}{l}\text { Омская область, Респуб- } \\
\text { лика Башкортостан }\end{array}$ & $\begin{array}{l}\text { Тосол, эпоксидные смолы, изопропилбензол для } \\
\text { производства современных композитных, строи- } \\
\text { тельных материалов, лекарств и парфюмерии }\end{array}$ \\
\hline $\begin{array}{l}\text { Кластер трубопроводной } \\
\text { арматуры }\end{array}$ & $\begin{array}{l}\text { Курганская и Челябинская } \\
\text { области, Пермский край }\end{array}$ & $\begin{array}{l}\text { Оборудование для крупных нефтяных и газовых } \\
\text { месторождений }\end{array}$ \\
\hline $\begin{array}{l}\text { Кластер деревянного домо- } \\
\text { строения и деревообработки }\end{array}$ & $\begin{array}{l}\text { Вологодская и Новгород- } \\
\text { ская области }\end{array}$ & Выпуск деревянных домокомплектов \\
\hline $\begin{array}{l}\text { Промышленный кластер } \\
\text { метровагоностроения }\end{array}$ & $\begin{array}{l}\text { Тверская и Московская } \\
\text { области }\end{array}$ & Метровагоностроение \\
\hline
\end{tabular}

Примечание. Составлено автором.

Межрегиональное кластерное сотрудничество может в ряде случаев открыть возможность продвижения проектов, которые не соответствуют критериям поддержки в региональном («ячеечном») формате. Так, посредством объединения маршрутных точек туристических направлений регионы, которые остаются за бортом ФЦП «Развитие туризма в РФ на период 2019-2025 гг.», могут получить ресурсы развития в межрегиональном формате.

Таким образом, в РФ имеются специальные инструменты развития, допускающие возможность межрегиональной интеграции в их рамках (см. табл. 2).

В целом можно говорить о фрагментарно реализованном принципе межрегиональности в формировании соответствующих инструментов. Однако потенциал таких инструментов может способствовать формированию условий реализации подобного рода ориентации специальных инструментов на методологическом уровне и уровне управленческих механизмов.
Векторы акселерации использования специальных инструментов развития в интересах межрегиональной интеграции. Система мер усиления межрегионального вектора рассматриваемых инструментов на методологическом уровне может включать пересмотр подхода, который оперирует «регионами» как изолированными «адресатами» мер государственной политики, в рамках которой особые инструменты содействия развитию прочно увязаны с уникальными особенностями положения регионов (приграничность, стратегическое положение, анклавность), что имеет следствием:

- укрепление вертикальных (в ущерб горизонтальным), ориентированных на бюджетирование «сверху», связей регионов, выделенных по тому или иному критерию;

- отсутствие стимулов поиска внутренних ресурсов, одним из которых является синергия межсубъектного взаимодействия;

- косвенное стимулирование сохранения параметров (депрессивных) регионов ввиду отсутствия общности траекторий их развития с иными регионами; 


\section{Инструменты развития регионов Российской Федерации по критерию возможности межрегиональной интеграции в их рамках}

\begin{tabular}{|c|c|}
\hline $\begin{array}{c}\text { Инструменты, } \\
\text { допускающие организацию } \\
\text { по принципу межрегиональности }\end{array}$ & $\begin{array}{c}\text { Инструменты, не допускающие организацию } \\
\text { по принципу межрегиональности }\end{array}$ \\
\hline $\begin{array}{l}\text { Особые экономические зоны } \\
\text { (за исключением «региональ- } \\
\text { ных» особых экономических зон) }\end{array}$ & $\begin{array}{l}\text { Особые экономические зоны в границах Калининградской и Магадан- } \\
\text { ской областей }\end{array}$ \\
\hline \multirow{6}{*}{$\begin{array}{l}\text { Промышленные кластеры } \\
\text { (согласно Постановлению Пра- } \\
\text { вительства РФ от 28.01.2016 } \\
\text { № 41) }\end{array}$} & Территории опережающего развития \\
\hline & $\begin{array}{l}\text { Геостратегически значимые территории (Калининградская область, Рес- } \\
\text { публика Карелия) }\end{array}$ \\
\hline & «Свободный порт Владивосток» \\
\hline & Регионы с низким уровнем социально-экономического развития \\
\hline & $\begin{array}{l}\text { Промышленные технопарки (согласно Федеральному закону от } \\
31.12 .2014 \text { № 488-ФЗ «О промышленной политике в Российской Феде- } \\
\text { рации» (ст. 19.1 «Промышленные технопарки» введена Федеральным } \\
\text { законом от 27.06.2018 № 160-Ф3)) }\end{array}$ \\
\hline & 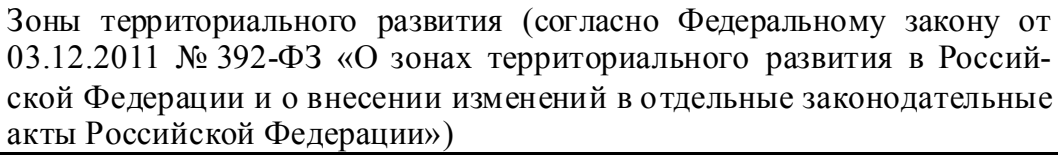 \\
\hline
\end{tabular}

Примечание. Составлено автором.

- отсутствие (ввиду игнорирования межсубъектного взаимодействия) развития институциональных условий и бюджетных механизмов хозяйственно-сетевого взаимодействий субъектов (что отчасти компенсируется связями рыночного сектора).

Напротив, создание институцииональных условий межрегионального взаимодействия за рамками представительских контактов регионов расширяет потенциал их инфраструктурного развития, роста качества социального обеспечения населения, решения экологических (часто межрегиональных) проблем, вопросов природопользования. Создание таких условий возможно посредством таких мер, как:

- ограничение финансирования инструментов, основанных на исключительности параметров регионов, с перенаправлением льгот и субсидий на механизмы, учитывающие возможность межрегионального взаимодействия;

- разработка и внедрение для регионов, отличающихся особыми параметрами, инструментария их развития, включающего задействование инвестиционных, транспортно-коммуникационных (инфраструктурных), производственно-кооперационных связей с сопредельными регионами;

- формирование бюджетного и законодательного инструментария расширения меж- региональной деятельности ОЭЗ и кластерных проектов;

- внедрение возможности межрегионального формата строго регионально ориентированных инструментов.

Механизмы акселерации межрегиональной составляющей специальных инструментов развития при этом могут быть дифференцированы в зависимости от их задач (см. табл. 3).

Следует отметить, что предлагаемые меры должны вводиться в режиме дополнительных мер, не ухудшающих условия специальных инструментов. Кроме того, возможны разработка и введение новых форматов таких инструментов на основе указанных принципов и механизмов, а также коррекция существующих практик ввиду окончания срока действия ряда программ в 2020 году. Также может быть расширено действие уже имеющихся инструментов на основе их пространственного расширения (если это не противоречит законодательству).

\section{Выводы}

Сложившиеся подходы к стимулированию регионального развития посредством особых инструментов лишь отчасти учитывают потенциал межрегионального взаимодей- 


\begin{tabular}{|c|c|c|c|}
\hline \multirow[b]{2}{*}{$\begin{array}{c}\text { Сферы реализации } \\
\text { межрегионального } \\
\text { взаимодействия }\end{array}$} & \multicolumn{3}{|c|}{ Цели инструментов } \\
\hline & $\begin{array}{l}\text { Стимулирование регионов - } \\
\text { лидеров роста }\end{array}$ & $\begin{array}{l}\text { Упрочение геоэкономического } \\
\text { и геостратегического присут- } \\
\text { ствия }\end{array}$ & $\begin{array}{l}\text { Выравнивание (повыше- } \\
\text { ние) уровня социально- } \\
\text { экономического развития }\end{array}$ \\
\hline $\begin{array}{l}\text { Стимулирование } \\
\text { спроса }\end{array}$ & \multicolumn{3}{|c|}{$\begin{array}{l}\text { Меры стимулирования поставок продукции в сопредельные / другие российские ре- } \\
\text { гионы }\end{array}$} \\
\hline $\begin{array}{l}\text { Технико- } \\
\text { технологическое } \\
\text { развитие }\end{array}$ & $\begin{array}{l}\text { - льготирование импорта } \\
\text { оборудования для простран- } \\
\text { ственно распределенных зон } \\
\text { развития / кластеров; } \\
\text { - возмещение затрат инно- } \\
\text { вационного импорта в слу- } \\
\text { чае межрегионального про- } \\
\text { изводства }\end{array}$ & $\begin{array}{l}\text { - льготирование импорта } \\
\text { оборудования для простран- } \\
\text { ственно распределенных зон } \\
\text { развития / кластеров; } \\
\text { - возмещение затрат инно- } \\
\text { вационного импорта в слу- } \\
\text { чае межрегионального про- } \\
\text { изводства }\end{array}$ & $\begin{array}{l}\text { - амортизационные } \\
\text { стимулы обновления } \\
\text { ОПФ; } \\
\text { - льготирование импор- } \\
\text { та оборудования для } \\
\text { пространственно рас- } \\
\text { пределенных зон разви- } \\
\text { тия / кластеров }\end{array}$ \\
\hline $\begin{array}{l}\text { Повышение рента- } \\
\text { бельности рези- } \\
\text { дентов }\end{array}$ & \multicolumn{3}{|c|}{$\begin{array}{l}\text { Налоговые вычеты и дополнительное ступенчатое понижение ставок налогов в зави- } \\
\text { симости от уровня межрегиональности }\end{array}$} \\
\hline $\begin{array}{l}\text { Инфраструктурное } \\
\text { развитие }\end{array}$ & \multicolumn{2}{|c|}{$\begin{array}{l}\text { Государственное софинансирование инфраструктуры IT, } \\
\text { R\&D в ареалах развития на основе межрегиональности }\end{array}$} & $\begin{array}{l}\text { Софинансирование раз- } \\
\text { вития межрегиональных } \\
\text { инфраструктур транс- } \\
\text { порта и связи }\end{array}$ \\
\hline $\begin{array}{l}\text { Кадровое обеспе- } \\
\text { чение }\end{array}$ & \multicolumn{3}{|c|}{$\begin{array}{l}\text { Содействие привлечению кадров региона базирования и сопредельных регионов за } \\
\text { счет софинансирования целевого обучения, профориентации }\end{array}$} \\
\hline
\end{tabular}

Примечание. Составлено автором.

ствия. Однако оно способно повысить как эффективность развития в целом, так и действенность самих соответствующих инструментов. В качестве мер, направленных на учет потенциала межрегиональности таковых, можно указать меры в области методологических подходов, в институциональной сфере и в сфере механизмов стимулирования на федеральном уровне. Причем последние целесообразно дифференцировать в зависимости от того, с какой целью применяется специальный инструмент регионального развития.

\section{ПРИМЕЧАНИЕ}

${ }^{1}$ Исследование выполнено в рамках проекта РФФИ № 18-010-00015 «Модели, эффекты, стратегии и механизмы включения западного порубежья России в систему “горизонтальных" межрегиональных экономических связей в контексте формирования “Большой Евразии”»).

The reported study was funded by RFBR, project no. 18-010-00015 "Models, Effects, Strategies and Mechanisms of the Inclusion of the Western Borderline of Russia into the System of 'Horizontal' Interregional Economic Relations in the Context of the 'Greater Eurasia'”.

\section{СПИСОК ЛИТЕРАТУРЫ}

Алтухов, А. И. Совершенствование межрегиональных продовольственных связей в стране: вопросы методологии и практики / А. И. Алтухов // Агропродовольственная политика России. 2017. - № 2 (62). - C. 2-11.

Ахунов, Р. Р. Развитие межрегиональной интеграции как направление повышения конкурентоспособности в системе воспроизводственного потенциала региона / Р. Р. Ахунов // Вестник УГНТУ. Наука, образование, экономика. Серия: Экономика. -2016. -№ 1 (15). - С. 7-17.

Бакуменко, О. А. Проблемы и перспективы межрегионального взаимодействия периферийных регионов Северо-Западного федерального округа / О. А. Бакуменко // Региональная экономика: теория и практика. - 2017. T. 15, № 3 (438). - C. 459-470. - DOI: https:// doi.org/10.24891/re.15.3.459.

Борщик, Н. Д. Межрегиональные связи субъектов Российской Федерации: теория и практика / Н. Д. Борщик // Политика, экономика и инновации. - 2016. - № 3 (5). - Электрон. текстовые дан. - Режим доступа: http://pei-journal.ru/ index.php/PEII/article/view/71/html. - Загл. с экрана.

Гибадуллин, М. 3. Межрегиональные экономические связи Чувашской Республики: тенденции 
и перспективы / М. З. Гибадуллин, А. Р. Артамонычева // Вестник Чувашского университета. - 2013. - № 2. - С. 249-253.

Доклад о мировых инвестициях - 2019. Особые экономические зоны / ЮНКТАД. Нью-Йорк ; Женева : [б. и.], 2019. - Электрон. текстовые дан. - Режим доступа: https://unctad.org/en/ PublicationsLibrary/wir2019_overview_ru.pdf.Загл. с экрана.

Колодина, Е. А. Роль государства в регулировании межрегиональной интеграции / Е. А. Колодина // Известия Иркутской государственной экономической академии. - 2003. - № 2. C. $62-68$.

Котлярова, С. Н. Практика формирования кластеров в регионах России / С. Н. Котлярова // Региональная экономика: теория и практика. 2012. - № 24. - C. 29-39.

Лукин, Е. В. Межрегиональные связи: состояние и проблемы развития (на примере Вологодской области) / Е. В. Лукин // Экономические и социальные перемены: факты, тенденции, прогно3. - 2012. - № 6 (24). - С. 205-217.

Методические рекомендации по организации межрегионального и межмуниципального сотрудничества в сфере реализации расходных полномочий и вопросов местного значения. М. : М-во регион. развития РФ, 2010.

Михайлов, А. С. Формирование международных кластеров в Балтийском регионе / А. С. Михайлов // Балтийский регион. - 2013. - № 1 (15). - С. 53-66.

Отчет о результатах функционирования особых экономических зон за 2018 год и за период с начала функционирования особых экономических зон. - Электрон. текстовые дан. - Режим доступа: https://economy.gov.ru/. - Загл. с экрана.

Ручкин, А. В. Реализация проектов межмуниципального сотрудничества: обзор российской и зарубежных практик / А. В. Ручкин, Н. К. Шеметова // Муниципалитет: экономика и управление. - 2014. - № 4 (9). - С. 5-12.

Смоленко, А. Н. Особенности формирования трансграничных кластеров / А. Н. Смоленко // Экономические исследования и разработки. - 2016. - № 5. - С. 123-129.

СП не увидела прорывного влияния преференциальных режимов на экономику России. 09.07.2020. - Электрон. текстовые дан. - Режим доступа: https://ach.gov.ru/checks/sp-neuvidela-proryvnogo-vliyaniya-preferentsialnykhrezhimov-na-ekonomiku-rossii. - Загл. с экрана.

Топилин, А. В. Межрегиональные и межмуниципальные связи как средство преодоления дезинтеграционных тенденций в экономическом пространстве России / А. В. Топилин, В. Г. Ро- станец, А. И. Кабалинский // Вестник РАЕН. 2015. - Т. 15, № 6. - С. 87-94.

\section{REFERENCES}

Altuhov A.I. Sovershenstvovanie mezhregionalnykh prodovolstvennykh svyazey v strane: voprosy metodologii i praktiki [Improving Interregional Food Relations in the Country: Issues of Methodology and Practice]. Agroprodovolstvennaya politika Rossii [Agri-Food Policy of Russia], 2017, no. 2 (62), pp. 2-11.

Ahunov R.R. Razvitie mezhregionalnoy integratsii kak napravlenie povysheniya konkurentosposobnosti v sisteme vosproizvodstvennogo potentsiala regiona [Development of Interregional Integration as a Direction of Increasing Competitiveness in the System of Reproductive Potential of the Region]. Vestnik UGNTU. Nauka, obrazovanie, ekonomika. Seriya: Ekonomika. [UGNTU Bulletin. Science, Education, Economics. Series: Economics], 2016, no. 1 (15), pp. 7-17.

Bakumenko O.A. Problemy i perspektivy mezhregionalnogo vzaimodeystviya periferiynykh regionov Severo-Zapadnogo federalnogo okruga [Problems and Prospects of Interregional Interaction ofPeripheral Regions of the North-Western Federal District]. Regionalnaya ekonomika: teoriya $i$ praktika [Regional Economy: Theory and Practice], 2017, vol. 15, no. 3 (438), pp. 459-470. DOI: https:// doi.org/10.24891/re.15.3.459.

Borshchik N.D. Mezhregionalnye svyazi subyektov Rossiyskoy Federatsii: teoriya i praktika [Interregional Relations of the Constituent Entities of the Russian Federation: Theory and Practice]. Politika, ekonomika i innovatsii [Politics, Economics and Innovation], 2016, no. 3 (5). URL: http://pei-journal.ru/index.php/ PEII/article/view/71/html.

Gibadullin M.Z., Artamonycheva A.R. Mezhregionalnye ekonomicheskie svyazi Chuvashskoy respubliki: tendentsii i perspektivy [Interregional Economic Ties of the Chuvash Republic: Trends and Prospects]. Vestnik Chuvashskogo universiteta [Bulletin of Chuvash University], 2013, no. 2, pp. 249-253.

UNCTAD. Doklad o mirovykh investitsiyakh -2019. Osobye ekonomicheskie zony [World Investment Report - 2019. Special Economic Zones]. New York, Geneva, [s. n.], 2019. URL: https://unctad.org/en/PublicationsLibrary/ wir2019_overview_ru.pdf.

Kolodina E.A. Rol gosudarstva $v$ regulirovanii mezhregionalnoy integratsii [The Role of the State in Regulating Interregional Integration]. 
Izvestiya Irkutskoy gosudarstvennoy ekonomicheskoy akademii. [Izvestia of the Irkutsk State Economic Academy], 2003, no. 2, pp. 62-68.

Kotlyarova S.N. Praktika formirovaniya klasterov v regionakh Rossii [The Practice of Forming Clusters in the Regions of Russia]. Regionalnaya ekonomika: teoriya i praktika. [Regional Economy: Theory and Practice], 2012, no. 24 , pp. 29-39.

Lukin E.V. Mezhregionalnye svyazi: sostoyanie i problemy razvitiya (na primere Vologodskoy oblasti) [Interregional Relations: State and Problems of Development (On the Example of the Vologda Oblast]. Ekonomicheskie $i$ sotsialnye peremeny: fakty, tendentsii, prognoz [Economic and Social Changes: Facts, Trends, Forecast], 2012, no. 6(24), pp. 205-217.

Metodicheskie rekomendatsii po organizatsii mezhregionalnogo i mezhmunitsipalnogo sotrudnichestva $v$ sfere realizatsii raskhodnykh polnomochiy $i$ voprosov mestnogo znacheniya [Methodical Recommendations on the Organization of Interregional and InterMunicipal Cooperation in the Field of the Implementation of Spending Powers and Issues of Local Importance]. Moscow, Ministerstvo regionalnogo razvitiya RF Publ., 2010.

Mikhaylov A.S. Formirovanie mezhdunarodnykh klasterov v baltiyskom regione [Formation of the International Clusters in the Baltic Region]. Baltiyskiy region [The Baltic Region], 2013, no. 1 (15), pp. 53-66.

Otchet o rezultatakh funktsionirovaniya osobykh ekonomicheskikh zon za 2018 god i za periods nachala funktsionirovaniya osobykh ekonomicheskih zon [Report on the Results of Special Economic Zones for 2018 and from the Beginning of Special Economic Zones]. URL: https://economy.gov.ru.

Ruchkin A.V. Realizatsiya proektov mezhmunitsipalnogo sotrudnichestva: obzor rossiyskoy i zarubezhnykh praktik [Implementation of Projects of Inter-Municipal Cooperation: An Overview of Russian and Foreign Practices]. Munitsipalitet: ekonomika i upravlenie [Municipality: Economics and Management], 2014, no. 4 (9), pp. 5-12.

Smolenko A.N. Osobennosti formirovaniya transgranichnykh klasterov [Features of the Formation of Transboundary Clusters]. Ekonomicheskie issledovaniya $i$ razrabotki [Economic Research and Development], 2016, no. 5, pp. 123-129.

SP ne uvidela proryvnogo vliyaniya preferencialnykh rezhimov na ekonomiku Rossii [SP Did not See a Breakthrough Effect of Preferential Regimes on the Russian Economy]. 2020. URL: https:// ach.gov.ru/checks/sp-ne-uvidela-proryvnogovliyaniya-preferentsialnykh-rezhimov-naekonomiku-rossii.

Topilin A.V., Rostanec V.G., Kabalinskij A.I. Mezhregionalnye i mezhmunitsipalnye svyazi kak sredstvo preodoleniya dezintegratsionnykh tendentsiy $\mathrm{v}$ ekonomicheskom prostranstve Rossii [Interregional and Inter-Municipal Relations as a Means of Overcoming Disintegration Trends in the Economic Space of Russia]. Vestnik RAEN [Vestnik RAYEN], 2015, vol. 15, no. 6, pp. 87-94.

\section{Information About the Author}

Nikolay W. Gontar, Candidate of Sciences (Geography), Associate Professor, Leading Researcher, Southern Federal University, Pushkinskaya St, 160, 344006 Rostov-on-Don, Russian Federation, passat01@mail.ru, https://orcid.org/0000-0002-7310-1828

\section{Информация об авторе}

Николай Владимирович Гонтарь, кандидат географических наук, доцент, ведущий научный сотрудник, Южный федеральный университет, ул. Пушкинская, 160, 344006 г. Ростов-наДону, Российская Федерация, passat01@mail.ru, https://orcid.org/0000-0002-7310-1828 